\title{
The Effects of Acebutolol Alone and in Combination with Furosemide or Hydralazine in Experimentally Induced Hypertensive G-minipigs
}

\author{
Yukio YASUDA, Hiroshi HIDAKA*, Susumu SAWADA* \\ and Yoshikuni TANIOKA
}

\begin{abstract}
Central Institute for Experimental Animals, 1430 Nogawa, Miyamae, Kawasaki 213, Japan, and *First Department of Internal Medicine, Faculty of Medicine, The University of Tokyo, Bunkyo-ku, Tokyo 113.
\end{abstract}

(Received 3 September 1985/Accepted 10 June 1986)

\begin{abstract}
Experimentally induced hypertensive G-minipigs were used for assessing the antihypertensive effects of acebutolol, a cardioselective $\beta$-adrenergic blocking agent. In the acute experiment, six females were used. Acebutolol $(3 \mathrm{mg} / \mathrm{kg}$, i.v. $)$ alone or in combination with furosemide $(1 \mathrm{mg} / \mathrm{kg}$, i.v. $)$ or hydralazine $(1 \mathrm{mg} / \mathrm{kg}$, i.v. $)$ was administered through an implanted catheter. In the chronic experiments, five females received oral acebutolol (100-200 mg/day). The blood pressure, heart rate, plasma renin activity (PRA) and plasma aldosterone concentration (PAC) were used as parameters. In the acute experiment, there were no marked changes in the blood pressure or heart rate during the nondosing period. Acebutolol alone caused a marked decrease in the blood pressure and heart rate. In the two combination tests, combined administration with acebutolol and furosemide had a greater effect on the blood pressure and heart rate than did acebutolol alone. A combined acebutolol and hydralazine regimen caused a slight reduction not only in the blood pressure, but also in the heart rate compared with acebutolol alone. PRA and PAC remained essentially constant, with minor fluctuations, throughout the nondosing period. Following the injection of acebutolol alone, PRA showed an elevation with a significant rise after three hours and PAC showed a tendency to increase. PRA and PAC generally tended to increase in the case of combined administration with furosemide or hydralazine, but these tendencies were less conspicuous than with acebutolol alone. On the other hand, chronic treatment with acebutololproduced a significant decrease in the heart rate from two weeks after the administrationand in the blood pressure from four weeks. When subsequent doses were changed, no dose-related changes in systolic or diastolic pressure occurred two weeks after medication and only systolic pressure decreased significantly four weeks after treatment. The heart rate showed no further response to an increase in acebutolol dose. As mentioned above, hypertensive G-minipigs receiving acebutolol alone or in combination with furosemide or hydralazine showed antihypertensive effects.
\end{abstract}

In a previous paper [12], the authors have reported experimentally induced hypertension in Göttingen miniature pigs (G-minipigs) with unilateral nephrectomy and high sodium chloride loading. It is necessary to confirm whether or not an antihypertensive effect is actually produced when the hypertensive G-minipigs are given antihypertensive agents. We have reported a pharmacological comparison of angiotensin converting enzyme inhibitor using Gminipigs in in vivo and in vitro experimental systems [6]. No report has been made 
concerning the evaluation of antihypertensive agents using G-minipigs. In this study, the acute and chronic antihypertensive effects of acebutolol, a selective $\beta$-adrenergic agent, were evaluated in conscious G-minipigs with experimentally induced hypertension.

\section{Materials and Methods}

Six (Group A) and five (Group B) female $\mathrm{G}$-minipigs, ranging from six to eight months of age and 19 to $24 \mathrm{~kg}$ in body weight, were unilaterally nephrectomized and loaded with 1 $\%$ physiological saline $(2,000 \mathrm{ml} /$ day $)[12]$ and deoxycorticosterone acetate $(100 \mathrm{mg} /$ week, i.m. $)$ [5]. A catheter was implanted in the jugular vein [11] and blood was drawn through the catheter. The blood was transferred to a test tube containing EDTA, and the plasma was

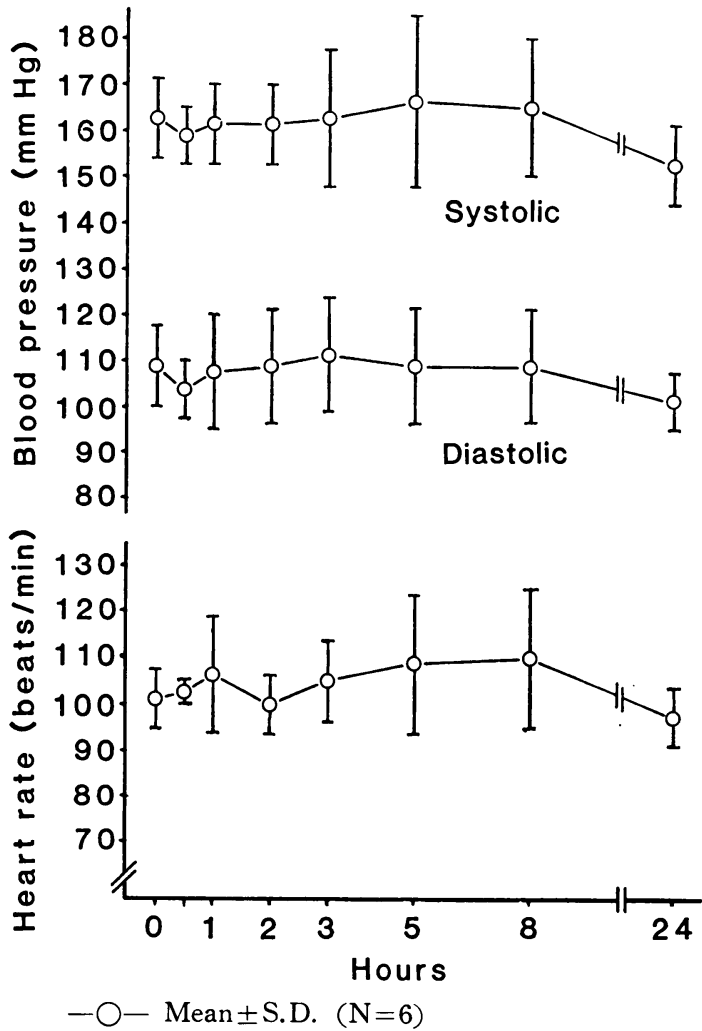

Significant differences were not observed as compared with the predosing $(0 \mathrm{hr})$ period.

Fig. 1. Acute changes in the blood pressure and heart rate in the nondcsing period. separated with a cooled centrifuge. To measure the blood pressure and heart rate under nonanesthesized conditions, the animals were suspended using a chinning apparatus. The blood pressure and heart rate were measured using an oscillometric sphygmomanometer (Nippon Colin Co., Ltd.). Plasma renin activity (PRA) and plasma aldosterone concentration (PAC) were determined using a radioimmunoassay kit (Dainabot Inc.).

Group A was used for experiments on the acute antihypertensive effects. The diurnal variation in the blood pressure and heart rate, as well as PRA and PAC levels were observed in each hypertensive G-minipig. A solution of the drugs was administered through a catheter. Acebutolol hydrochloride (Acebutolol ${ }^{\circledR}$;

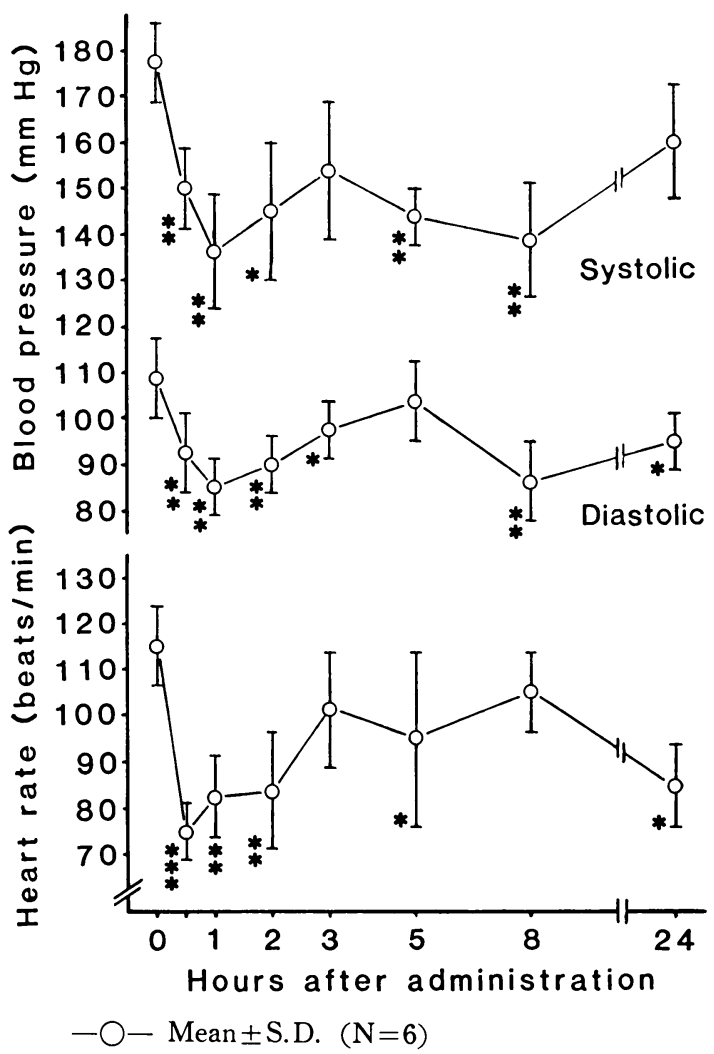

Significant differences were evaluated as compared with predosing $(0 \mathrm{hr})$ period. $* \mathrm{P}<0.05$ ** $\mathrm{P}<0.01$ *** $\mathrm{P}<0.001$

Fig. 2. Acute changes in the blood pressure and heart rate following the administration of acebutolol alone. 
Rhone-Poulenc) was given in a dose of $3 \mathrm{mg} /$ $\mathrm{kg}$, alone or concomitantly with $1 \mathrm{mg} / \mathrm{kg}$ of furosemide (Lasix ${ }^{\circledR}$; Hoechst, a hypotensive diuretic) or $1 \mathrm{mg} / \mathrm{kg}$ of hydralazine hydrochloride (Apresolin ${ }^{\circledR}$; Ciba, a vasodilator). Each hypertensive G-minipig was given the regimens of these single and combination tests three times at 10-day intervals. Control experiments, i.e., the nondosing period, were performed before dosing.

Group B was used for experiments on the chronic antihypertensive effect and received oral acebutolol doses of 100,200 and $100 \mathrm{mg} /$ day for the first and second four weeks and the next two weeks, respectively. Measurement of the blood pressure and heart rate and also blood sampling for measurement of PRA and

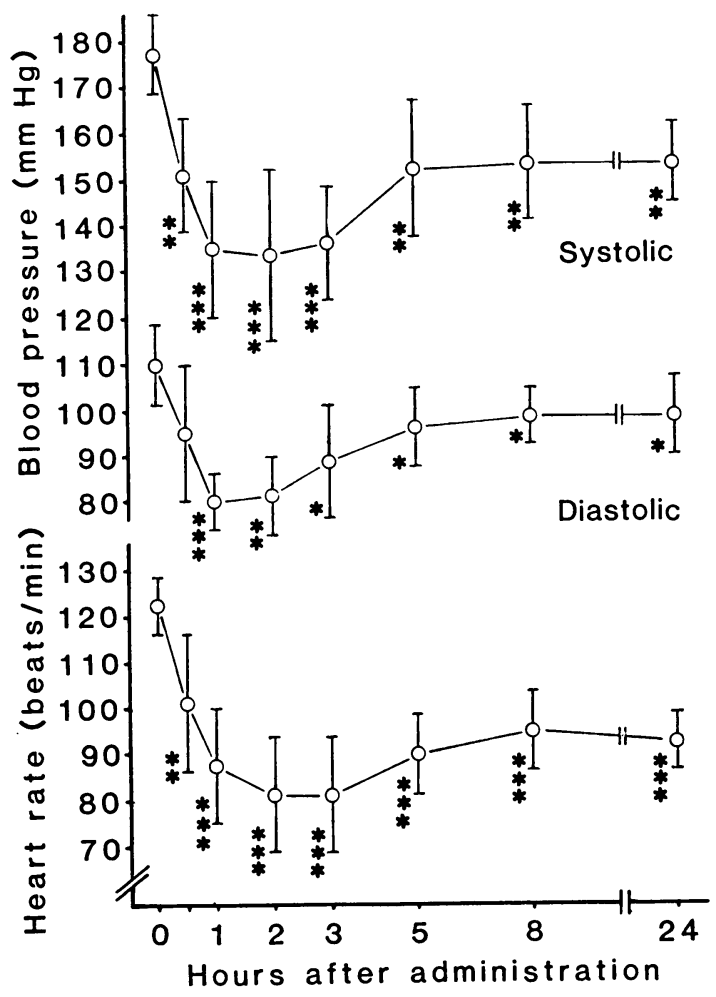

- - Mean \pm S.D. $(\mathrm{N}=6)$

Significant differences were evaluated as compared with the predosing $(0 \mathrm{hr})$ period.

$* \mathrm{P}<0.05$ ** $\mathrm{P}<0.01$ *** $\mathrm{P}<0.001$

Fig. 3. Acute changes in the blood pressure and heart rate following the combined adminstration of acebutolol and furosemide.
PAC were performed.

Statistical analysis was conducted by means of analysis of variance and Student's $t$-test for predosing observations. The $95 \%$ limits of probability were accepted as significant.

\section{Results}

Concerning the acute effects of acebutolol alone or in combination with furosemide or hydralazine on the heart rate and blood pressure, the hypertensive G-minipigs exhibited a virtually constant blood pressure and heart rate with no noticeable diurnal variation during the nondosing period (Fig. 1). In response to an injection of acebutolol alone, both the blood pressure and heart rate decreased significantly
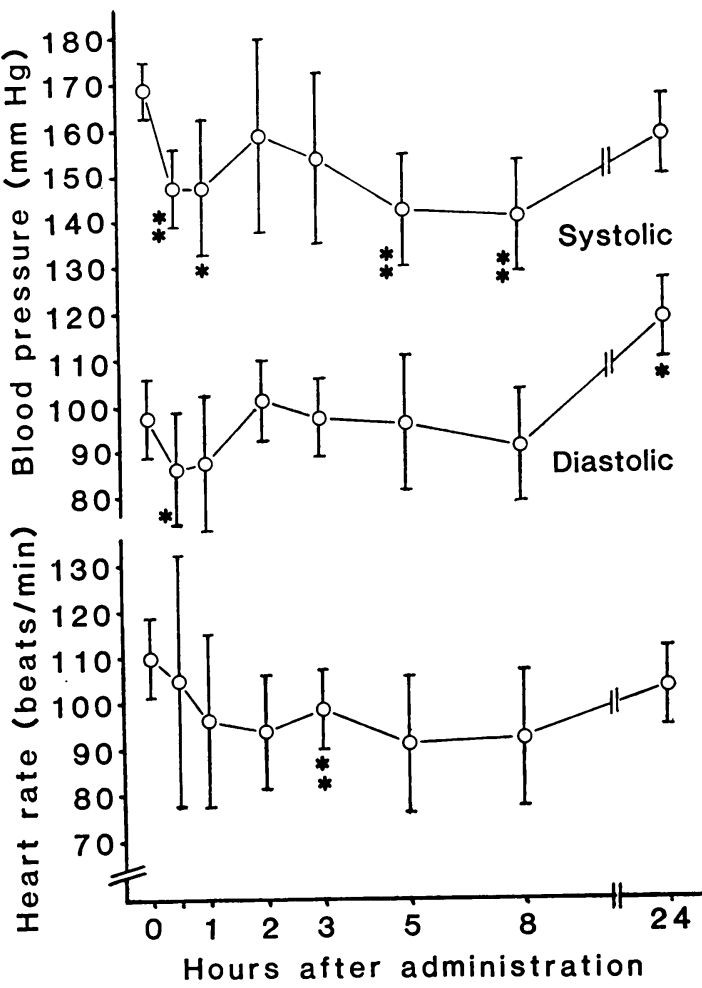

$-O-$ Mean \pm S.D. $(\mathrm{N}=6)$

Significant differences were evaluated as compared with the predosing ( $0 \mathrm{hr}$ ) period.

$* \mathrm{P}<0.05$ ** $\mathrm{P}<0.01$

Fig. 4. Acute changes in the blood pressure and heart rate following the combined administration of acebutolol and hydralazine. 
Table 1. Changes in the plasma renin activity and plasma aldosterone concentration after the administration of the agents in the acute experiment.

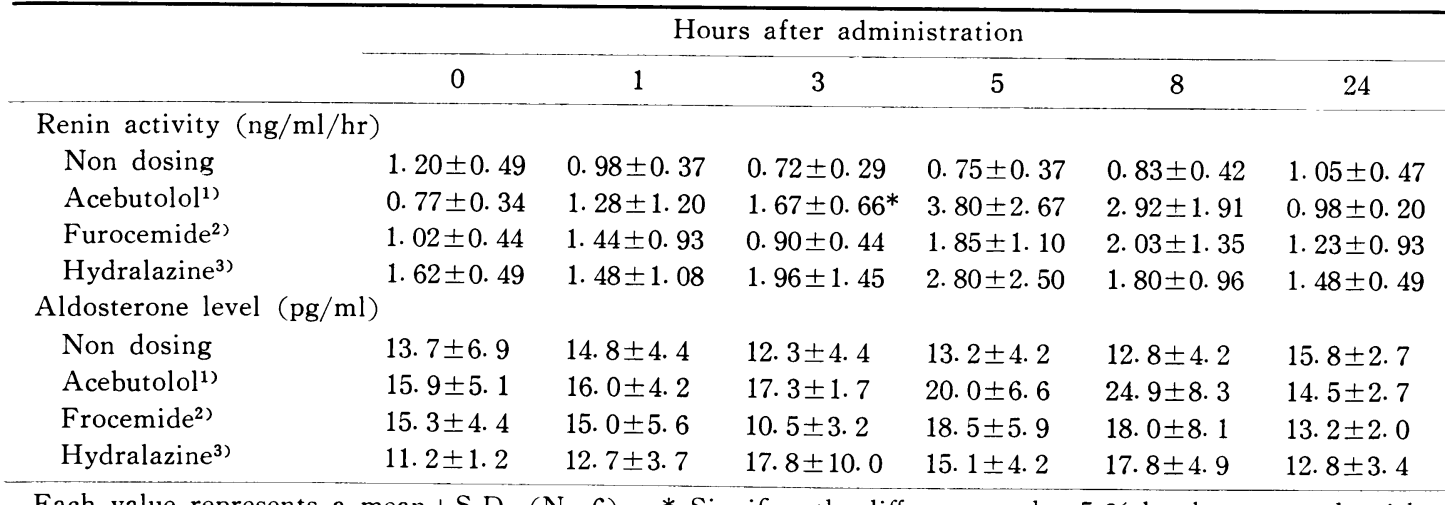

Each value represents a mean \pm S.D. $(\mathrm{N}=6)$. * Significantly different at the $5 \%$ level compared with predosing (0 hr) period.

1) Acebutolol alone

2) Combined administration of acebutolol and furocemide.

3) Combined administration of acebutolol and hydralazine.

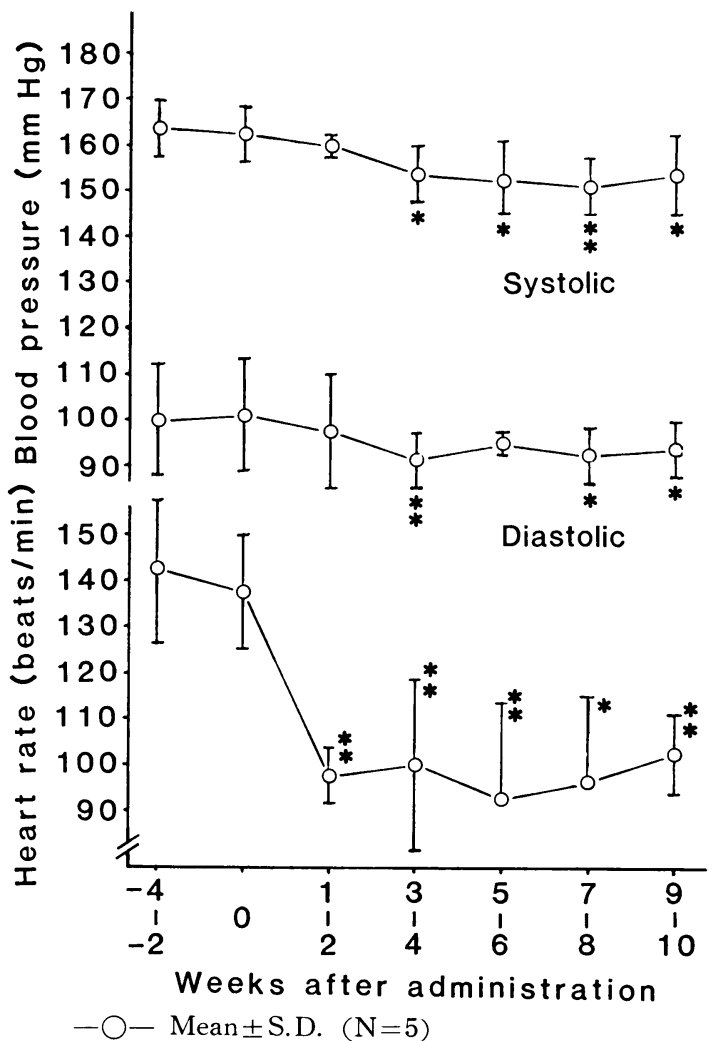

Significant differences were evaluated as compared with the predosing ( 0 week) period.

$* \mathrm{P}<0.05 * * \mathrm{P}<0.01$ compared with the predosing level (Fig. 2). Combined injection of acebutolol and furosemide also produced a significant decrease in blood pressure and heart rate, and the effect was sustained longer than that after the administration of acebutolol alone (Fig. 3). A combined acebutolol and hydralazine regimen caused a slight reduction in heart rate and blood pressure compared with acebutolol alone (Fig. 4).

Both PRA and PAC remained essentially constant, with minor diurnal changes throughout the nondosing period (Table 1). Following administration of acebutolol alone, both parameters showed elevations, with a significant rise in PRA after three hours and a tendency to increase in PAC after eight hours. PRA and PAC generally tended to increase following the administration of acebutolol in combination with furosemide or hydralazine, but the elevations were less conspicuous than those seen with acebutolol alone.

Concerning the chronic effect of acebutolol, Fig. 5 shows the time-course of the blood

$\leftarrow$ Fig. 5. Time course of the blood pressure and heart rate after the oral administration of acebutolol. G-minipigs were given doses of 100,200 and $100 \mathrm{mg} /$ day for the first and second four weeks and the next two weeks, respectively. 
pressure and heart rate throughout the experimental period. The heart rate decreased significantly from two weeks after the administration, but significant decreases in blood pressure were observed from four weeks after medication. When subsequent doses were changed, no dose-related changes in systolic or diastolic pressures occurred two weeks after medication and only systolic pressure was significantly decreased four weeks after treatment. The heart rate showed no further response to an increase in acebutolol dose.

PRA and PAC were measured before and after acebutolol treatment. Chronic treatment with acebutolol tended to increase PRA and PAC (data not shown).

\section{Discussion}

In a study conducted using various strains of rats, Takami et al. [9] observed that acebutolol suppressed the blood pressure when administered by the intraperitoneal route. On the other hand, it has been shown that intravenous injection of $\beta$-blockers produced an elevation of blood pressure in rats $[4,10]$. In the present study of treatment with acebutolol alone, the decline in systolic and diastolic pressures tended to correlate well with the decrease in heart rate. This may be interpreted as a direct manifestation of decreased cardiac output by the cardioselective action of the $\beta$-blocker acebutolol causing only a slight constriction of peripheral blood vessels.

Single oral doses of $400 \mathrm{mg}$ of acebutolol brought about a significant, prolonged decrease in the heart rate and blood pressure in normal subjects and hypertensive patients $[1,3]$. In this study, the cardiovascular system of hypertensive G-minipigs showed a good response acutely and chronically to acebutolol dosages.

The present data on acebutolol in hypertensive G-minipigs, unlike those obtained in rats $[4$, $9,10]$, were in good agreement with the results in humans $[1,3]$. This implies that Gminipigs exhibit similar cardiovascular responses to the drugs in humans.

Brunner et al. [2] and Kubo et al. [7] have reported their observations regarding the effects of $\beta$-blocker predosing on hydralazine- induced blood pressure and heart rate changes. In this study, the animals showed a slight decrease of heart rate and blood pressure in response to the combined administration of acebutolol and hydralazine as opposed to with acebutolol alone, thus indicating a decrease in the hypertensive effect of acebutolol with hydralazine. The increase in the heart rate that occurs following the administration of hydralazine is interpreted as resulting from a reflexive cardiostimulating effect of vasodilation. The suppression of the antihypertensive effect of acebutolol by the concomitant administration of hydralazine seen in this study seems to suggest that the tachycardiac effect of hydralazine is due to cardiac stimulation by this vasodilator.

The combined use of hypotensive-diuretics and $\beta$-blockers is widely seen clinically. It has been noted that enhancement of the antihypertensive effects of hypotensive-diuretics by the concomitant administration of a $\beta$-blocker is attributable to inhibition by the hypotensive diuretic-induced increase of renin secretion [4]. Nielsen and coworkers [8] observed a marked enhancement of the effect in dogs and rats receiving both drugs, and the enhancement became evident two days after the administration and thereafter. In this study, the animals given combined acebutolol-furosemide regimens also responded with a greater, longer-sustained decline in blood pressure when compared with acebutolol alone.

It is known that $\beta$-blockers generally decrease PRA. However, an increase of PRA occurred following the administration of acebutolol in the present study. G-minipigs with high sodium chloride loading showed suppression of the renin aldosterone system [12]. Accordingly, it is suggested that the administration of acebutolol did not cause a decrease in PRA. It can also be assumed that an intrinsic sympathomimetic effect of acebutolol was manifested as stimulated renin secretion, not associated with its effects on the blood pressure and heart rate.

As mentioned above, hypertensive Gminipigs receiving acebutolol alone or in combination with furosemide or hydralazine exhibited antihypertensive effects. These findings imply that G-minipigs exhibited cardiovascular 
responses to the drugs similar to those in humans.

\section{Acknowledgements}

Part of this study was supported by a grant-in-aid for New Drug Development Research from the Ministry of Health and Welfare. We would also like to thank RhonePoulenc Yakuhin K. K. for their gift of acebutolol.

\section{Refirenc:s}

[1] Atarashi, K., Ishii, M., Yamamoto, M., Hirata, Y., Uehara, Y., Ikeda, S., and Takeda, T. (1982). Acute hypotensive effect of acebutolol in healthy males. J. Med. Pharmacol. Sci., 7, 972-980.

[2] Brunner, H., Hedwall, P. R., and Meier, M. (1967). Influence of beta-blocking agents on the cardiovascular action of hydralazine. Br. J. Pharmacol. Chemother., 30, 123-133.

[3] Cody, R. J., Jr., Tarazi, R. C., Bravo, E. L., and Foud, F. M. (1978). Multifactorial analysis of the antihypertensive effect of acebutolol. Bata-blockade in clinical practice; Current trends: Proceedings of Satellite Symposium-the VIII World Congress of Cardiology, Tokyo.

[ 4 ] Forman, B. H., and Mulrow, P. J. (1974). Effect of propranolol on blood pressure and plasma renin activity in the spontaneously hypertensive rats.
Cir. Res., 35, 215-221.

[ 5 ] Grekin, R. J., Terris, J. M., and Bohr, D. F. (1980). Electrolyte and hormonal effects of deoxycorticosterone acetate in young pigs. Hypertension 2, 326-332.

[6] Hidaka, H., Sawada, S., Sato, R., Oka, H., and Yasuda, Y. (1985). Pharmacological comparison of captopril and MK-422 by a new method for measuring activity of angiotensin converting enzyme (ACE). Jpn. Circ. J., 49, 1175-1179.

[7] Kubo, T., Yamashita, M., and Misu, Y. (1981). Effect of beta-blocking agents on the cardiovascular action of hydralazine in conscious rats. Jpn. J. Pharmacol., 31, 1087-1090.

[ 8 ] Nielsen, C. K., Olsen, U. B., Ronne, I. A., and Martelli, E. A. (1976). Investigations on the antihypertensive activity of timolol and bendrofulmethiazide and combination(s) in dogs and rats. Acta Pharmacol. Toxicol., 39, 500-512.

[9] Takami, N., Sugawara, K., and Ozaki, M. (1979). Effect of acebutolol, a cardioselective $\beta$-adrenoceptor blocking agent, on the blood pressure in rats. Folia Pharmacol. Jpn., 75, 747-754.

[10] Yamamoto, J., and Sekiya, A. (1969). On the pressor action of propranolol in rats. Arch. Int. Pharmacodyn., 179, 372-380.

[11] Yasuda. Y., Tanioka, Y., and Ohsawa, N. (1982). Adrenocortical function in pigs-Circadian variations and episodic secretion patterns in plasma cortisol. Jpn. J. Zootech. Sci., 53, 441-444.

[12] Yasuda, Y., Hidaka, H., and Tanioka, Y. (1983). Some observations on experimental hypertension in minipigs. Exp. Anim., 32, 185-189.

\title{
高血圧ミニブタ Gにおけるアセブトロール単独ならびに フロセミドあるいはヒドララジンとの併用投与の影響
}

\author{
安田幸雄・日高 宏*. 沢田進*. 谷岡功邦 \\ 財実験動物中央研究所 \\ *東京大学医学部第 1 内科
}

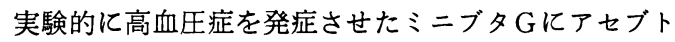
ロール(心蔵選択性アドレナリン性受容体の遮断剂)を投 与した場合の降圧勃果を検討した。急性実験では, メス 6 頭を用い, アセブトロール $(3 \mathrm{mg} / \mathrm{kg}$, i.v. $)$ の単独投 与およびアセブトロールとフロセミド ( $1 \mathrm{mg} / \mathrm{kg}$, i.v. $)$ あるいはヒドララジン $(1 \mathrm{mg} / \mathrm{kg}$, i.v.) の併用投与試験 を行なった。慢性実験では, メス 5 頭を用い,アセブトロ ール (100-200mg/頭/日, p.o.) の単独投与を行なった。
\end{abstract}

指標として, 血圧, 心拍数および血浆レニン活性 (PRA), 血浆アルドステロン濃度 (PAC) を用いた。急性実験に おける薬物投与前の試験では, 血圧, 心拍数ともにほほ 一定した值で推移した。アセブトロール単独投与試験で は, 血圧, 心拍数ともに顕著な低下がみられた。併用投 与試験のうち, アセブトロールとフロセミドとの併用投 与では, アセブトロール単独投与の場合よりも血圧, 心 拍数に対する抑制効果が大きかった。また，アセブトロ 
ールとヒドララジンとの併用投与では，アセブトロール 単独投与の場合よりも血圧，心拍数の低下は顕著でなく 降圧効果は小さかった。PRA および PAC について は，薬物投与前の試験では大きな変化はみられなかっ た。アセブトロールの単独投与では, PRA は投与後 3 時間で有意な上昇がみられ，PAC は上昇傾向がみられ た。併用投与試験では，いずれの試験においても PRA および PAC の上昇傾向がみられたが，アセブトロール 単独投与の場合之異なり, 上舁は小さかった。一方, ア セブトロール単独投与の慢性実験に抢いては, 心拍数は
投与 2 週目以降で, 血压は 4 週目以降で有意な低下がみ られた。アセブトロールの増量投与後, 収縮期圧, 拡張 期压のいずれも 2 週目までは降圧効果は顕著ではなく, 4 週目に収縮期压の抑制効果がみられた。心拍数につい ては顕著な抑制効果はみられなかった。また，PRAお よび PAC は投与後上昇する傾向がみられた。以上よ り，実験的に高血压症を発症させたミニブタ Gにアセブ トロールを投与した場合に顕著な降圧効果が得られた。 とくに，アセブトロールとフロセミドとの併用投与で は, 降压効果はさらに顕著であった。 